\title{
General Attitudes of Middle School Students Towards Physical Education 中學生對體育課的態度
}

\author{
David Barney \\ Department of Teacher Education, \\ Brigham Young University, U.S.A. \\ Robert Christenson \\ Department of Applied Health \& Educational Psychology, \\ Oklahoma State University, U.S.A. \\ 大衛賓尼 \\ 美國楊百翰大學教師教育學系 \\ 羅伯特基斯滕森 \\ 美國奧克拉荷馬州大學應用健康及教育心理學系
}

\begin{abstract}
Attitudes are formed by beliefs and experiences a person has had in their life (Silverman \& Subramanian, 1999). This principle applies to middle school students' attitudes in physical education. The purpose of this study was to determine middle school students' attitudes towards physical education. For this study 227 middle school students in the Midwest of the United States were surveyed, then 28 students were interviewed regarding the attitudes towards physical education. It was found that middle school students tend to have positive attitudes towards physical education more specifically, the student felt that physical education is important their education and that the activities they participate in are fun and the physical education class is an important aspect of a students' school day.
\end{abstract}

\section{摘 要}

態度是由個人生活的信念和經驗所形成的（Silverman和Subramanian，1999）。這一原則適用於初中學生的對體育課的態 度。本研究的目的是要確定中學生對體育課的態度。本研究有227名中學生參與, 在美國中西部地區進行調查, 然後28名學生再 進行面訪對體育的態度。結果發現, 中學生往往對體育課有積極的態度, 學生認為體育是重要的教育, 參加活動感覺很有趣, 體 育課是學生的一個重要學習天。

\section{Introduction}

What is it about physical education class for middle school students? For some students they thoroughly enjoy the games and activities, and for other students barely stand being in class. In many cases, it is the attitudes the students bring with them to class. Attitudes are formed by beliefs and experiences a person has in their life (Silverman \& Subramanian, 1999). This applies for students in physical education. The literature has revealed some of the variables that affect student's attitudes towards physical education class. 
One of the main variables that affect student attitudes is the curriculum. Rickard \& Banville (2006) investigated high school student's attitudes about their physical education curriculum regarding fitness and sport activities. The researchers found high school students had a greater preference for game play then fitness activities. The high school student's also expressed the importance of having variety in the activities they participated in. Some of the student's felt that since they were in high school, they had covered all of the traditional activities (basketball, flag football, volleyball, football, softball) throughout their physical education experience. Thus the students wanted to learn new and novel activities to experience in their high school physical education class.

Tannehill \& Zakrajsek (1993) focused on the affects the curriculum has on student attitudes with a multicultural emphasis. They looked at middle and high school student's attitudes towards physical education and sport from a multicultural perspective. The researchers found that Anglo-American students liked physical education because they could be with their friends. Asian-American students liked physical education because they liked playing volleyball. And African-American students liked physical education because they could play basketball. Of all the multicultural groups, none of them liked or enjoyed participating in fitness activities.

Another variable the literature has found to affect student attitudes is the teacher. Ryan, Fleming \& Maina (2003) studied the affects the teacher has on student attitudes towards physical education. It was found that the physical education teacher did favorably affect student attitudes towards physical education. The students in the study liked that their physical education teacher had "good physical skills", "they were friendly," and they "allowed the class to help plan activities." With a large majority being favorably influenced by the teacher there was some students that felt contrary to their peers. Some of the student's felt that their physical education teacher "could not relate to students," and were "prejudiced towards my race." Another study dealing with how the teachers affect student attitudes investigated gender differences in adolescent's attitudes (Luke \& Sinclair, 1991). In this study the researchers created five determinants that positively and negatively affected high school student attitudes towards physical education. The five determinants for this study were: 1) the curriculum, 2) class atmosphere, 3) self-perception, 4) the teacher, and 5) the facilities. It was found that the teacher was the second most influential determinant, both positively and negatively for high school student's attitudes towards physical education. Some of the comments the students made regarding the teacher were, "held high expectations," "focused on learning something," and "provided not just a play class." The student's continued to say that they valued and appreciated a sensitive teacher. Someone that "encouraged me despite my low ability" and "a teacher that does not force me to run if I feel unwell." The results from this study suggest that the teacher is a powerful determinant of student attitudes towards physical education.

As the literature has so well stated the effects of the curriculum and the teacher in affecting student attitudes towards physical education, there is a need to continue to investigate this topic. Silverman \& Subramaniam (1999) suggest that student attitude research in physical education may be attributed to future participation in physical activity, thus their needs to be continuous research in student attitudes towards physical education. For this reason the purpose of this study was to determine middle school students' attitudes toward physical education.

\section{Methods}

\section{Participants}

The participants for this study consisted of students from a middle school in an upper Midwestern city in the United State. The students $(n=227)$ came from intact classes comprised of $6^{\text {th }}, 7^{\text {th }}$, and $8^{\text {th }}$ graders. The university institutional review board granted permission to conduct this study. Prior to the start of the study, the researcher met with classroom teachers and principal and proposed the intentions of the study. Permission to conduct the study was given by the school principal. Parental consent was obtained. The survey was administered on site.

\section{Instrumentation}

The instrument used for this study, the Physical Education Interest Questionnaire (PEIQ) was developed to measure interest in physical education and related factors (Van Wersch, Trew, \& Turner, 1992). The survey was used in a pilot study and it was found to be .70 reliable. During the pilot study the author's established content validity of the survey. The total number of items on the 
survey was 35. Within the survey, six sub-areas were created. They were: 1) interest in physical education; 2) the degree to which students construe physical education as a subject with masculine or feminine connotation: 3) how students construed physical education compared with other school subjects; 4) satisfaction or dissatisfaction with the class curriculum; 5) effect the physical education teacher has on the students; and 6) physical changes middle school students are experiencing and the effects they have on their attitudes (Barney \& Deutsch, 2010). For the purpose of this study, six questions (2, 4, 5, $6,16, \& 17)$ on the survey dealing with satisfaction or dissatisfaction with physical education were analyzed.

Table 1. Physical Education Interest Questionnaire.

\section{Physical Education Survey}

When completing the survey, honestly answer the questions below. Answer the question by circling one of the three responses:

1) Agree, 2) Neutral, and 3) Disagree.

Thank you for your help.

\section{Background Questions $\quad$ Circle Your Answer}

1. What grade are you in? $\quad 6^{\text {th }} \quad 7^{\text {th }} \quad 8^{\text {th }}$

2. Sex: Male Female

3. Age: $\begin{array}{llllll}10 & 11 & 12 & 13 & 14 & 15\end{array}$

4. Who is your teacher? Mr.

Ms.

\section{$\underline{\text { Survev Questions }}$}

1. Sometimes I pretend to be ill so that I do not have to do PE.

2. I would take part in PE even if I did not have to.

3. I never forget to bring my PE clothes.

4. Even when I do not feel well, I do not want to miss PE.

5. I wish they did not make us do PE, because it is not important.

6. I like doing PE because it is fun

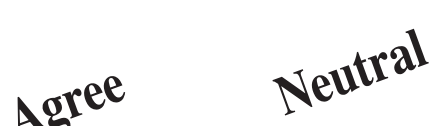

7. PE is not for me because I am not strong and big enough.

8. I do not like PE because it is only about winning and beating your opponent.

9. I like physical exercise which are strenuous and painful. .I prefer physical exercise which havebeauty in movement such as in dance and gymnastic.

11. I prefer those activities in PE which do not make me tired and sweaty.

12. I do not like playing games because they are too rough.

13. I do not go to school to do PE, but to learn more important subjects.

14. PE at school is not important because you can do sports in your spare time.

15. PE is not important because you cannot get a job by doing it. 
16. I would prefer it if PE were as important as other school subjects.

17. I would rather do PE than other school subjects.

18. I find the activities in PE boring because we always do the same things.

19. .I wish we could choose what we do in PE.

20. I would prefer to play less games and have more fitness activities in PE.

21. I do not like competing against others; I would rather compete against myself as in fitness tests.

22. .I do not like doing the same games every lesson.

23. I think the sports played in PE and games are fine.

24. My PE teacher does not treat students who are good at PE differently from the others.

25. When we learn new skills in PE my PE teacher only helps the good students.

26. My PE teacher does not pay much attention to the students who are not very good at games and activities.

27. The PE teacher usually gives more help to the students who are good at PE than to the ones who are not good at it.

28. My PE teacher does not pay more attention to the students who are good at PE than to the ones who are less good.

29. PE would be much more fun if the PE teacher did not praise only the good students.

30. Sometimes I feel I have no control over my body in PE activities and I trip over my own feet.

31. I have always been good at PE. Table 1 cont.

Physical Education Interest Questionnaire

32. I sometimes have the feeling that my arms and legs are not doing what I want them to do in PE.

33. I do not like others watching me while I am doing activities in PE.

34. I do not like trying any new activity in

PE in case somebody laughs at me.

35. I sometimes have the feeling that others are laughing at 1 me while I am doing an activity.

\section{Interviews}

After the survey was completed and analyzed, the researchers conducted a second part of data collection, student interviews. For this study, 28 students were interviewed. After the surveys were analyzed 14 students who responded positively and 14 students who responded negatively to the survey were interviewed. The researchers reasoned that 28 students would give a good picture of student attitudes towards their physical education experience. The number of questions asked and analyzed to each student was determined by their responses from the survey. Every student was not asked the same amount questions. The researchers analyzed all of the interview data, but for this study, the six survey statements regarding physical education were analyzed.

\section{Data Analysis}

The data were analyzed using descriptive statistics in the Statistical Package for the Social Science (SPSS) 
program. Percentages were used to reflect the student's responses for each item being analyzed. A 3-point Likert scale was used. The following numerical values were given for every student response: $1=$ Agree, $2=$ Neutral and $3=$ Disagree. When analyzing the data the following variables were investigated: a) grade levels: $6^{\text {th }}, 7^{\text {th }}$, and $8^{\text {th }}$, and b) gender (male $(n=118)$ and female $(n=109)$ for each grade level.

\section{Results}

Survey questions 2, 4, 5, 6, 16, \& 17 were examined for this study. Table 2 provides information regarding student's attitudes towards physical education.

Table 2. Results of Student Attitudes Towards Physical Education.

2) I would take part in PE even if I did not have to.

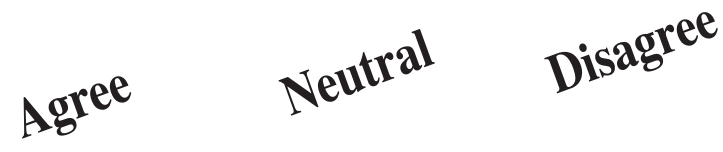

$\begin{array}{llll}\text { 6th Grade } & 64 \% & 25 \% & 11 \% \\ \text { M } & 78 \% & 15 \% & 7 \% \\ \text { F } & 60 \% & 24 \% & 16 \% \\ 7^{\text {th }} \text { Grade } & & & 12 \% \\ \text { M } & 68 \% & 20 \% & 4 \% \\ \text { F } & 86 \% & 10 \% & 14 \% \\ 8^{\text {th }} \text { Grade } & 52 \% & 34 \% & 7 \% \\ \text { M } & & & 4 \% \\ \text { F } & 69 \% & 24 \% & 19 \%\end{array}$

4) Even when I do not feel well, I do not want to miss PE.

$\begin{array}{llll}6^{\text {th }} \text { Grade } & 48 \% & 29 \% & 23 \% \% \\ \mathrm{M} & 58 \% & 33 \% & 9 \% \\ \mathrm{~F} & 31 \% & 43 \% & 26 \% \\ 7^{\text {th }} \text { Grade } & 43 \% & 39 \% & 18 \% \\ \mathrm{M} & 58 \% & 33 \% & 9 \% \\ \mathrm{~F} & 31 \% & 43 \% & 26 \% \\ 8^{\text {th }} \text { Grade } & & & 13 \% \\ \mathrm{M} & 50 \% & 37 \% & 12 \% \\ \text { F } & 61 \% & 27 \% & 19 \%\end{array}$

5) I wish they did not make us do PE, because it is not important.

$\begin{array}{llll}6^{\text {th }} \text { Grade } & 3 \% & 13 \% & 84 \% \\ \mathrm{M} & 2 \% & 0 \% & 98 \% \\ \mathrm{~F} & 5 \% & 16 \% & 79 \% \\ 7^{\text {th }} \text { Grade } & 4 \% & 9 \% & 87 \% \\ \mathrm{M} & 2 \% & 0 \% & 98 \% \\ \mathrm{~F} & 5 \% & 16 \% & 79 \%\end{array}$




$\begin{array}{llll}8^{\text {th }} \text { Grade } & 1 \% & 18 \% & 81 \% \\ \text { M } & 2 \% & 10 \% & 88 \% \\ \text { F } & 0 \% & 44 \% & 56 \%\end{array}$

6) I like doing PE because it is fun.

$\begin{array}{llll}6^{\text {th }} \text { Grade } & 77 \% & 20 \% & 3 \% \\ \mathrm{M} & 87 \% & 9 \% & 4 \% \\ \mathrm{~F} & 72 \% & 21 \% & 7 \% \\ 7^{\text {th }} \text { Grade } & & & 6 \% \\ \mathrm{M} & 79 \% & 15 \% & 4 \% \\ \mathrm{~F} & 87 \% & 9 \% & 7 \% \\ 8^{\text {th }} \text { Grade } & 72 \% & 21 \% & 13 \% \\ \mathrm{M} & & & 0 \% \\ \mathrm{~F} & 50 \% & 37 \% & 0 \%\end{array}$

16) I would prefer it if PE were as important as other school subjects.

$\begin{array}{llll}6^{\text {th }} \text { Grade } & 25 \% & 40 \% & 35 \% \\ \text { M } & 24 \% & 44 \% & 32 \% \\ \text { F } & 20 \% & 47 \% & 33 \% \\ & & & \\ 7^{\text {th }} \text { Grade } & & 46 \% & 26 \% \\ \text { M } & 28 \% & 42 \% & 33 \% \\ \text { F } & 25 \% & 40 \% & 38 \% \\ 8^{\text {th }} \text { Grade } & 22 \% & & 30 \% \\ \text { M } & & 49 \% & 28 \% \\ \text { F } & 21 \% & 44 \% & 40 \%\end{array}$

17) I would rather do PE than other school subjects.

$\begin{array}{llll}6^{\text {th }} \text { Grade } & 26 \% & 42 \% & 32 \% \\ \mathrm{M} & 48 \% & 28 \% & 24 \% \\ \mathrm{~F} & 25 \% & 46 \% & 29 \% \\ 7^{\text {th }} \text { Grade } & & & 24 \% \\ \mathrm{M} & 28 \% & 48 \% & 32 \% \\ \mathrm{~F} & 23 \% & 45 \% & 29 \% \\ 8^{\text {th }} \text { Grade } & 22 \% & 49 \% & 27 \% \\ \mathrm{M} & & & 24 \% \\ \mathrm{~F} & 17 \% & 56 \% & 30 \%\end{array}$


Statement two states, "I would take part in PE even if I did not have do," For both male and female students, over $60 \%$ would take physical education class even if students did not have to. For this same question $64 \%$ of $6^{\text {th }}$ graders, $68 \%$ of $7^{\text {th }}$ graders and $69 \%$ of $9^{\text {th }}$ graders agreed with this statement. For the fourth survey statement, which states, "Even when I do not feel well, I do not want to miss PE." For the male students over 58\% and for the female students no more then $31 \%$ would not miss PE if they did not feel well. When analyzing the grade level data from this survey statement $48 \%$ of $6^{\text {th }}$ graders, $43 \%$ of $7^{\text {th }}$ graders and $50 \%$ of $8^{\text {th }}$ graders would not miss PE if they were not feeling well. Interestingly, 29\% of $6^{\text {th }}$ graders, 39\% of $7^{\text {th }}$ graders and $37 \%$ of $8^{\text {th }}$ graders were neutral in their attitudes for this statement.

For statement five, which states, "I wish they did not make us do PE, because it is not important." Overwhelmingly students from each grade disagreed with this statement $\left(6^{\text {th }}\right.$ grade: $84 \%, 7^{\text {th }}$ grade: $87 \%, \& 9^{\text {th }}$ grade: $81 \%$ ). The data for the male student revealed that there was a large majority that disagreed with this statement (over 88\% disagreed). One interesting finding from the data was that $44 \%$ of $8^{\text {th }}$ grade females were neutral in their response to this question. For statement six it states, "I like doing PE because it is fun." Students in $6^{\text {th }}$ grade $(77 \%)$ and $7^{\text {th }}$ grade $(79 \%)$ agreed with this statement. As far as the $8^{\text {th }}$ graders, $50 \%$ of students agreed with this statement. The data for both males (over 81\%) and females (over 63\%) agreed with this statement.

Data from statement 16, which states, "I would prefer it if PE were as important as other school subjects." A majority of students from all three grades were neither in agreement or disagreement. The majority of the students were neutral in their response to this statement $\left(6^{\text {th }}\right.$ graders: $40 \%, 7^{\text {th }}$ graders: $46 \%, \& 8^{\text {th }}$ graders: 49\%). The data for male students (44\%) and female students (49\%) were similar to the grade level data. Finally, the data from statement 17, which states, "I would rather do PE than other school subjects." Here again, a majority of the students were neutral in their attitudes regarding this question $\left(42 \%\right.$ for $6^{\text {th }}$ graders, $48 \%$ for $7^{\text {th }}$ graders, and $57 \%$ for $8^{\text {th }}$ graders). The data of attitudes for the males (43\%) and females 49\%) were similar.
The other data results from this study were the student interviews. The following are responses from the students from the six survey questions. When students were asked if they would take part in PE even if they did not have to, some of the student responses were, "I would still take PE because I hate sitting in class. I am an active person and like to run around." A number of students stated that PE was 'fun'. A couple of students stated that they "look forward to PE class and that it makes the rest of the day easier to get through." Students that were interviewed with negative attitudes, made statements such as "I don't like lots of sports and we play sports in class", "I'm not athletic and I am out of shape", and "there are a couple of people I don't like being around."

When analyzing student responses dealing with participation in activities when not feeling well, students stated, "It depends on the game. If we were running I wouldn't play," "No, because it is fun and stuff," and "Depends on how bad I feel. But if it wasn't that bad I would still play." The responses of students when asked regarding the importance of PE found students saying, "I feel it is important, because like you lift weights and it will help you to become stronger," "it helps your body get in shape and we can learn new things like lacrosse," and "Yea, because a lot of kids don't exercise at home. It is good for them to exercise at school." Student responses regarding fun in PE were, "I get to participate in games that are fun. I get to do it with my friends and its just fun," and "Because you get to run around and play games."

The student responses concerning the importance of PE found students to say, "I feel that if (PE) can help me now and it might help me when I am older," and "It wakes me up and I notice I am more awake for my other classes." And finally, the responses students gave regarding participation in PE rather than other school subjects. One $8^{\text {th }}$ grade student summed up this statement by saying, "My other school subjects are important, still coming and playing in PE makes school a lot more better for me." 


\section{Discussion}

The purpose of this study was to determine middle school students' attitudes towards physical education. The findings from this study indicate that middle school students tend to have positive attitudes towards physical education. For this reason, there are a couple items that should be discussed.

For statement four a majority of students would still take part in PE even if they did not feel well. Yet, when students were interviewed, some stated that if they were running they would not participate. These findings are similar to Bibik, Goodwin \& Omega-Smith (2007). When looking at the data in regards to the importance of PE, a majority of students feel it is important. Obviously, as physical educators we know of the importance physical education is in a students' education. But to have the students themselves voice their approval of physical education and its importance is another voice of support for physical education. Statement two also lends support and the importance of physical education. Once again a majority of middle school students feel that they would take part in PE even if they did not have to. Strand \& Scantling (1994) investigated secondary student preferences towards physical education. It was found that secondary students preferred team sports over individual sports, disliked crowded classes and have some say in activities they participate in. It was also found that $79 \%$ of the students indicated they would elect to enroll in physical education even if it was not a required subject.

When students respond by finding PE fun and making their day at school better, it shows the value physical education has among students. Statement 16 asked if students preferred PE to be as important as other school subjects. Students responded by saying, that it helps them now and will later in life and that because of their participation in physical education class it helps their learning in other classes. Stewart, Green, \& Huelskamp (1991) also looked at attitudes of junior high (grades 7-9) and high school (grades 10-12) students attitudes towards physical education. They found that $51 \%$ of the participants in their study either strongly agreed or agreed that it (PE) was as important as other school subjects. It was further stated by the students (82\%) that physical education should be retained in the curriculum.
The data suggests that middle school students have a positive attitude towards their physical education experience. The survey data also suggests that middle school students would still take PE class even if they did not have to, participate in class activities even if they were not feeling well, that PE class is fun, and that PE is as important as other school subjects. Results from this study once again emphasize the importance of attitudes and their role they are in middle school student physical education experience with the hope of leading to a life of physical activity.

\section{Implications for Teaching}

With the results that have been gleaned from this study, middle school physical educators should feel good about student attitudes towards physical education. Yet, middle school physical educators need to continue to provide a physical education program that will positively shape student attitudes with the hope that there students will grow up to be active adults. Graham (1995) has said that teaching and providing a high quality physical education program takes work, but if middle school physical educators make this a top priority, chances are better those students will benefit in many ways (psychomotor, cognitive \& affective) that will only enhance a students' life.

\section{References}

Barney, D. \& Deutsch, J. (2010). The effects of middle school physical education curriculum on student attitudes. Asian Journal of Physical Education \& Recreation, 15, (1), 12-20.

Bibik, J. M., Goodwin, S. C., \& Omega-Smith, E. M. (2007). High school students' attitudes toward physical education in Delaware. The Physical Educator, 64, 192-204.

Graham, G. (1995). Physical education through students' eyes and in student' voices: Implications for teachers and researchers. Journal of Teaching in Physical Education, 14, 478-482.

Luke, M. D. \& Sinclair, G. D. (1991). Gender differences in adolescents' attitudes toward school physical education. Journal of Teaching in Physical Education, 11, 31-46. 
Rickard, G. L., \& Banville, D. (2006). High school student attitudes about physical education. Sport, Education and Society, 11, 385-400.

Ryan, S., Fleming, D. \& Maina, M. (2003). Attitudes of middle school students towards their physical education teachers and classes. The Physical Educator, 60, 28-42.

Silverman, S., \& Subramaniam, P. R. (1999). Student attitudes toward physical education and physical activity: A review of measurement issues and outcomes. Journal of Teaching in Physical Education, 19, 96-124.

Stewart, M. J., Green, S. R., \& Huelskamp, J. (1991). Secondary students attitudes toward physical education. The Physical Educator, 48, 72-79.

Strand, B. \& Scantling, E. (1994). An analysis of secondary student preferences towards physical education. The Physical Educator, 51, (3), 197-201.

Tannehill, D. \& Zakrajsek, D. (1993). Student attitudes toward physical education: A multicultural study. Journal of Teaching in Physical Education, 13, 7884.

Van Wersch, A., Trew, K. \& Turner, I. (1992). Postprimary school pupils' interest in physical education: Age and gender differences. British Journal of Educational Psychology, 62, 56-72.

\section{Correspondence}

David Barney, Ed.D.

Department of Teacher Education,

Brigham Young University

249 G Smith Field House

Provo, Utah 84602

Email: David_Barney@byu.edu

Robert Christenson, Ed.D.

Assistant Professor

Oklahoma State University

188 Colvin Center, Stillwater, OK 74078

Phone: (405) 744-5502

Email: Robert.christenson@okstate.edu 